流 れ

\title{
Blue Skies Research
}

\author{
小西 昭充 ${ }^{1}$
}

1 群馬県前橋市昭和町3-39-22 群馬大学大学院医学系研究科生化学

\begin{tabular}{l} 
文献情報 \\
\hline 投稿履歴: \\
受付 平成29年 6 月 1 日 \\
採択 平成29年 6 月15日 \\
\hline 論文別刷請求先 : \\
小西昭充 \\
T371-8511 群馬県前橋市昭和町3-39-22 \\
電話: $027-220-7941$ 群馬大学大学院医学系研究科生化学 \\
E-mail: akimitsukonishi @ gunma-u.ac.jp \\
\hline
\end{tabular}

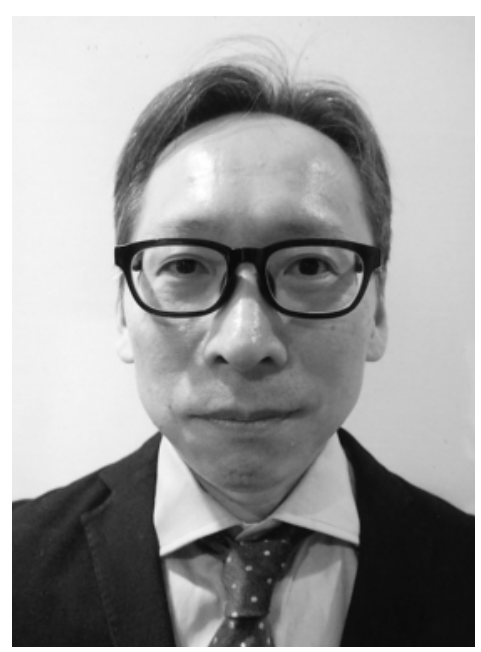

\section{DNA 損傷によるアポトーシス誘導}

細胞の染色体 DNA は常に損傷を受けるリスクを持って います，そのため, 細胞は様々な DNA 修復機構を持ち,さ らにDNA の損傷がシビアで修復が困難な場合には,アポ トーシス (細胞死) が誘導されて重度に損傷を受けた細胞 が体内に残らない仕組みを備えています. 呼吸器外科を数 年経験したのち, Bcl-2 遺伝子をクローニングして世界のア ポトーシス研究をリードしていた大阪大学, 辻本賀英教授 のもとで基礎研究を始めました. 研究を始めた 1998 年は, 細胞死の際, ミトコンドリアからシトクローム C が放出さ れ，アポトーシスが実行されるという一連の論文が Xiaodong Wang のグループから報告され，ミトコンドリア が一躍アポトーシス研究の最前線に出た頃でした. DNA 損傷によるアポトーシス刺激をミトコンドリアに伝達する 因子を見つけるというテーマで，X 線照射したラット胸腺 の細胞質抽出物をカラムで分画して, 肝臓から単離してき たミトコンドリアに反応させるという地道な作業を続け, リンカーヒストンの一つのサブタイプ (H1.2) を候補物質 として同定しました. 本来, 核に存在するクロマチンの構 成因子であるリンカーヒストンが細胞質から精製されてき たという予想外の結果でしたが, DNA 損傷を受けたクロ マチンからリンカーヒストンが遊離して細胞質に移動し, ミトコンドリアの膜透過性を六進させてシトクローム C を放出させるメカニズムを, 最終的に明らかにすることが
できました.リンカーヒストン H1.2 のノックアウトマウ スでは X 線照射によるアポトーシスが抑制されることも 分かり, 無事, 論文として発表することができました. ${ }^{1}$

\section{テロメアによる染色体末端保護}

その後, DNA 損傷応答の研究にテロメアが使えるので は?というアイデアを持って, ロックフェラー大学, Titia de Lange 教授の研究室に留学しました. 真核生物の染色体 は線状であるため, その末端は X 線などによる DNA二本 鎖切断で生じる切断端と区別がつきません. そこで, 染色 体末端に存在するテロメアが DNA 損傷反応から染色体末 端を保護しています。 de Lange 博士はヒトのテロメア DNA の配列を決定し, テロメアDNAに結合するシェル タリンと呼ばれるタンパク質複合体をほぼ全てクローニン グされたテロメア研究の第一人者で, 留学当時ちょうど, シェルタリン複合体がテロメアの染色体末端保護機能の中 心的役割を担っていることを明らかにしつつありました. シェルタリンを構成するタンパクの機能を制御すれば，テ ロメア機能を自在に操作できるのでは? という発想のも と, テロメア機能制御技術の開発に取り組みました. シェ ルタリン因子 TRF2 の温度感受性変異体を樹立して, 温度 によってテロメア機能の on/off を操作できるシステムを 確立し, 細胞周期特異的なテロメア保護の仕組みを明らか にすることができました. ${ }^{2}$ 
文科省が若手研究者の新しいキャリアパスとしてスター トさせたテニュアトラック制度のサポートにより帰国後, 東京医科歯科大学, 群馬大学でテロメア・DNA 損傷応答機 構によるゲノム恒常性維持のメカニズムに関する研究を続 けてきました. ${ }^{3-6}$ また，群馬大学着任後から “Genome Damage Discussion Group”という研究会を定期的に開催 しております，もし，ご興味のある先生方がいらっしゃい ましたら,ご連絡をいただければ幸いです。

\section{最後に}

“Blue Skies Research”とは実用性のみを追い求めない基 礎研究のことを指す言葉です. 基礎研究における出口戦略 が叫ばれて久しい昨今ですが，大きな成果を生んだ基礎研 究の多くが科学者の知的好奇心から始まっていることも事 実です，暗雲立ち込めるような現実にも向き合いながらも， 青空を飛ぶ鳥のように自由に好奇心の翼を広げることを忘 れず，今後も研究を続けていきたいと思います．最後にな りましたが，これまでご指導いただいた先生方，同僚の 方々には，様々なご支援により研究を続けてこられたこと に深く感謝いたします。

\section{引用文献}

1. Konishi A, Shimizu S, Hirota J, et al. Involvement of Histone H1.2 in Apoptosis Induced by DNA Double-Strand Breaks. Cell 2003; 114(6): 673-688.

2. Konishi A, de Lange $\mathrm{T}$, Cell cycle control of telomere protection and NHEJ revealed by a ts mutation in the DNA-binding domain of TRF2. Genes Dev 2008; 22(9): 1221-1230.

3. Shimizu S, Konishi A, Nishida Y, et al. Involvement of JNK in the regulation of autophagic cell death. Oncogene 2010; 29(14): 2070-2082.

4. Konishi A, Arakawa S, Yue X, et al. Involvement of Beclin 1 in Engulfment of Apoptotic Cells. J Biol Chem 2012; 287(17): 13919-13929.

5. Watanabe Y, Honda S, Konishi A, et al. Autophagy controls centrosome number by degrading Cep63. Nature Communications 2016; 7: 13508.

6. Konishi A, Izumi T, Shimizu S, TRF2 Protein Interacts with Core Histones to Stabilize Chromosome Ends. J Biol Chem 2016; 291(39): 20798-20810. 